\title{
Front Matter: Volume 10057
}

, "Front Matter: Volume 10057," Proc. SPIE 10057, Multimodal Biomedical Imaging XII, 1005701 (18 April 2017); doi: 10.1117/12.2275836

SPIE. Event: SPIE BiOS, 2017, San Francisco, California, United States 


\section{PROGRESS IN BIOMEDICAL OPTICS AND IMAGING}

\section{Multimodal Biomedical Imaging XII}

Fred S. Azar

Xavier Intes

Editors

28 January 2017

San Francisco, California, United States

Sponsored and Published by

SPIE 
The papers in this volume were part of the technical conference cited on the cover and title page. Papers were selected and subject to review by the editors and conference program committee. Some conference presentations may not be available for publication. Additional papers and presentation recordings may be available online in the SPIE Digital Library at SPIEDigitallibrary.org.

The papers reflect the work and thoughts of the authors and are published herein as submitted. The publisher is not responsible for the validity of the information or for any outcomes resulting from reliance thereon.

Please use the following format to cite material from these proceedings:

Author(s), "Title of Paper," in Multimodal Biomedical Imaging XII, edited by Fred S. Azar, Xavier Intes, Proceedings of SPIE Vol. 10057 (SPIE, Bellingham, WA, 2017) Seven-digit Article CID Number.

ISSN: 1605-7422

ISSN: 2410-9045 (electronic)

ISBN: 9781510605558

ISBN: 9781510605565 (electronic)

Published by

SPIE

P.O. Box 10, Bellingham, Washington 98227-0010 USA

Telephone +1 3606763290 (Pacific Time) · Fax +1 3606471445

SPIE.org

Copyright (@ 2017, Society of Photo-Optical Instrumentation Engineers.

Copying of material in this book for internal or personal use, or for the internal or personal use of specific clients, beyond the fair use provisions granted by the U.S. Copyright Law is authorized by SPIE subject to payment of copying fees. The Transactional Reporting Service base fee for this volume is $\$ 18.00$ per article (or portion thereof), which should be paid directly to the Copyright Clearance Center (CCC), 222 Rosewood Drive, Danvers, MA 01923. Payment may also be made electronically through CCC Online at copyright.com. Other copying for republication, resale, advertising or promotion, or any form of systematic or multiple reproduction of any material in this book is prohibited except with permission in writing from the publisher. The CCC fee code is $1605-7422 / 17 / \$ 18.00$.

Printed in the United States of America.

Publication of record for individual papers is online in the SPIE Digital Library.

\section{SPIE. DIGITAL}

Paper Numbering: Proceedings of SPIE follow an e-First publication model. A unique citation identifier (CID) number is assigned to each article at the time of publication. Utilization of CIDs allows articles to be fully citable as soon as they are published online, and connects the same identifier to all online and print versions of the publication. SPIE uses a seven-digit CID article numbering system structured as follows:

- The first five digits correspond to the SPIE volume number.

- The last two digits indicate publication order within the volume using a Base 36 numbering system employing both numerals and letters. These two-number sets start with 00, 01, 02, 03, 04, $05,06,07,08,09,0 A, 0 B \ldots 0 Z$, followed by 10-1Z, 20-2Z, etc. The CID Number appears on each page of the manuscript. 


\title{
Contents
}

\author{
$\checkmark \quad$ Authors \\ vii Conference Committee \\ ix Introduction
}

SESSION 1 INSTRUMENTS AND ALGORITHMS

1005703 Optical skin assessment based on spectral reflectance estimation and Monte Carlo simulation [10057-2]

1005704 Fiber based fast sparse sampling x-ray luminescence computed tomography [10057-3]

1005705 Investigation of burn effect on skin using simultaneous Raman-Brillouin spectroscopy, and fluorescence microspectroscopy [10057-4]

\section{SESSION 2 MICROSCOPY AND ENDOSCOPY}

1005706 Combined optical coherence tomography and hyper-spectral imaging [10057-5]

1005707 Multimodal fluorescence and photoacoustic microscopy in the frequency domain [10057-6]

1005709 Spectral band optimization for multispectral fluorescence imaging [10057-8]

\section{SESSION 3 CLINICAL APPLICATIONS}

10057 OD Real-time fluorescence target/background (T/B) ratio calculation in multimodal endoscopy for detecting GI tract cancer [10057-12]

10057 OF Novel hybrid technology for early diagnostics of sepsis [10057-15]

\section{SESSION 4 HYBRID AND PRECLINICAL IMAGING}

$10057 \mathrm{OH} \quad$ Combined multispectral spatial frequency domain imaging and computed tomography system for intraoperative breast tumor margin assessment [10057-17]

10057 Ol Multimodal non-contact photoacoustic imaging and optical coherence tomography using all optical detection [10057-18]

10057 OK New contrasts for $x$-ray imaging and synergy with optical imaging (Invited Paper) [10057-16] 


\section{POSTER SESSION}

10057 OL Profiling wrist pulse from skin surface by Advanced Vibrometer Interferometer Device [10057-21]

10057 OM A single pixel camera video ophthalmoscope [10057-22]

10057 OP Application of kernel method in fluorescence molecular tomography [10057-25]

10057 OS Multi-modality image registration for effective thermographic fever screening [10057-28] 


\section{Authors}

Numbers in the index correspond to the last two digits of the seven-digit citation identifier (CID) article numbering system used in Proceedings of SPIE. The first five digits reflect the volume number. Base 36 numbering is employed for the last two digits and indicates the order of articles within the volume. Numbers start with 00, 01, 02, 03, 04, 05, 06, 07, 08, 09, 0A, 0B...0Z, followed by 10-1Z, 20-2Z, etc.

Artal, P., OM

Attendu, Xavier, 06

Baikejiang, Reheman, OP

Ballmann, Charles, 05

Baver, Jacob R., 03

Baver-Marschallinger, Johannes, 01

Berer, Thomas, 07, 0l

Bohndiek, Sarah E., 09

Boudoux, Caroline, 06

Buchegger, Bianca, 07

Casamento, Jon, OS

Coker, Zachary, 05

Dwith, C. Y. N., OS

Gambin, A., OM

Ghassemi, Pejhman, OS

Godbout, Nicolas, 06

Gong, Yuanzheng, OD

Grabovskis, Andris, OF

Guay-Lord, Robin, 06

Hardeberg, Jon Y., 03

Hsu, Yu-Hsiang, OL

Ibey, Bennett L., 05

Irles, E., OM

Jacak, Jaroslaw, 07

Jiang, Yang, OD

Kanick, S. C., $\mathrm{OH}$

Kazune, Sigita, OF

Klar, Thomas A., 07

Krishnaswamy, $\mathrm{V}$., $\mathrm{OH}$

Kviesis-Kipge, Edgars, OF

Lancis, J., OM

Langer, Gregor, 07

Lee, Chih-Kung, OL

Lee, Hao-Xiang, OL

Lee, Shu-Sheng, OL

Leiss-Holzinger, Elisabeth, 0

Li, Changqing, 04, OP

Lochocki, B., OM

Lun, Michael, 04

Luthman, A. Siri, 09

Manzanera, S., OM

Marcinkevics, Zbignevs, OF

McClatchy, D. M. III, OH

Meng, Zhaokai, 05

Paulsen, K. D., $\mathrm{OH}$

Petrov, Georgi, 05

Pfefer, Joshua, OS

Pfeffer, Karoline, 07

Pogue, B. W., $\mathrm{OH}$
Rizzo, E. J., $\mathrm{OH}$

Rubins, Uldis, OF

Saknite, Inga, OF

Seibel, Eric J., OD

Spigulis, Janis, OF

Strupler, Mathias, 06

Tajahuerce, E., OM

Traverso, Andrew, 05

Troyanova-Wood, Maria, 05

Verdaasdonk, Rudolf, 03

Volceka, Karina, OF

Wang, Ge, OK

Wang, Quanzeng, OS

Wang, Thomas D., OD

Waterhouse, Dale J., 09

Wells, W. A., $\mathrm{OH}$

Yakovlev, Vladislav, 05

Zhang, Wei, 04

Zhao, Yue, OP 
Proc. of SPIE Vol. 10057 1005701-6

Downloaded From: https://www.spiedigitallibrary.org/conference-proceedings-of-spie on 26 Apr 2023 Terms of Use: https://www.spiedigitallibrary.org/terms-of-use 


\section{Conference Committee}

Symposium Chairs

James G. Fujimoto, Massachusetts Institute of Technology

(United States)

R. Rox Anderson, Wellman Center for Photomedicine,

Massachusetts General Hospital (United States)and Harvard School

of Medicine (United States)

Program Track Chairs

Tuan Vo Dinh, Fitzpatrick Institute for Photonics, Duke University (United States)

Anita Mahadevan-Jansen, Vanderbilt University (United States)

Conference Chairs

Fred S. Azar, Philips Medical Systems (United States)

Xavier Intes, Rensselaer Polytechnic Institute (United States)

Conference Program Committee

Caroline Boudoux, Ecole Polytechnique de Montréal (Canada)

Christophe Chefd'hotel, Ventana Medical Systems, Inc.

(United States)

Yu Chen, University of Maryland, College Park (United States)

Qianqian Fang, Massachusetts General Hospital (United States)

Sergio Fantini, Tufts University (United States)

Gultekin Gulsen, University of California, Irvine (United States)

Theodore J. Huppert, University of Pittsburgh (United States)

Tim Nielsen, Philips Research (Germany)

Vasilis Ntziachristos, Helmholtz Zentrum München GmbH (Germany)

Brian W. Pogue, Thayer School of Engineering at Dartmouth (United States)

Siavash Yazdanfar, GE Global Research (United States)

Arjun G. Yodh, University of Pennsylvania (United States)

\section{Session Chairs}

1 Instruments and Algorithms

Changqing Li, University of California, Merced (United States)

Xavier Intes, Rensselaer Polytechnic Institute (United States) 
2 Microscopy and Endoscopy

Caroline Boudoux, Ecole Polytechnique de Montréal (Canada)

Ben Sherlock, University of California, Davis (United States)

3 Clinical Applications

Stefan A. Carp, Athinoula A. Martinos Center for Biomedical Imaging (United States)

Xavier Intes, Rensselaer Polytechnic Institute (United States)

4 Hybrid and Preclinical Imaging

Ge Wang, Rensselaer Polytechnic Institute (United States)

Xavier Intes, Rensselaer Polytechnic Institute (United States) 


\section{Introduction}

Optical techniques offer the potential to contribute greatly to the expansion of clinical multimodality techniques. Their ability to image structural, functional, and molecular information at different spatial and temporal scales makes them very attractive to the biomedical community. There is critical need for new instrumental approaches and computational techniques to provide rapid, accurate and cost-effective means for acquisition, quantification and characterization of multimodal data. Multimodality approach can be understood as the combination of multiple optical techniques in an instrument and/or fusion of an optical technique with other well-established imaging modalities such as CT, MRI, US, or PET. These instrumental and computational methods will enable faster acceptance of novel imaging modalities into viable clinical and/or preclinical systems. The applications are diverse and range from imaging at the cellular level to the whole body while incorporating molecular, functional and anatomical information.

The conference objectives are to provide a forum:

- to review and share recent developments in novel multimodal imaging techniques,

- to report development of novel computational methods, and

- to bring together the optical imaging and image analysis communities.

Topics include, but are not limited to:

- Multimodal imaging integrating structural, molecular and functional information

- Multimodal microscopic imaging

- 2D, 3D, 4D tomographic and / or multi-spectral imaging

- Imaging analysis and/or image processing techniques applied to optical imaging (e.g. visualization, segmentation, registration)

- Multimodal imaging instrumentation and system design

- Detection and diagnostic analysis techniques which may provide better quantitative and/or diagnostic insight into clinical and pre-clinical imaging (e.g. methods for quantitative measurements, computer-assisted diagnosis)

- Imaging analysis and/or image processing techniques used to combine optical imaging with other imaging modalities (e.g. MR, x-ray, PET)

- Image analysis, computational methods and reconstruction approaches which may help bring optical imaging into the clinic (visual rendering of complex data set, novel algorithms for assisted optical reconstruction) 
- Clinical evaluation of these new technologies (physiological and functional interpretation of image data, visual perception and observer performances, validation of quantitative assessment of optical signatures in-vivo).

Fred S. Azar

Xavier Intes 